\title{
Industrial Pollution and its Ill Effects on Aquatic Fauna
}

\author{
Sheikh. Afaq Gowhar \\ College of Public Health and Health Informatics, University of Ha'il, Ha'il Kingdom of Saudi Arabia \\ *Corresponding Author: Sheikh. Afaq Gowhar, College of Public Health and Health Informatics, \\ University of Ha'il, Ha'il Kingdom of Saudi Arabia
}

\begin{abstract}
Industries and factories give off various pollutants into the environment including the land, air, and waters. It is estimated that about 50\% of all pollution is as a result of industrial and manufacturing activities. Pollutants discharged from the industries have widespread implications, and one of the unpleasant effects is on water bodies. Industries demand lots of water for efficient production such as cooling, cleaning. Effects of two leather dyes were investigated on blood chemistry on fresh water fish Cirrhinus mrigala (Ham.) MCV, TLC, and lymphocytes count with two leather dyes Bismarck brown and Acid leather brown with three different concentrations. The decreasing trend was observed in $\mathbf{M C V}$ on exposure to leather dyes. The effect was more with Acid leather brown exposure. The decreased MCV levels may be due to hypochromicmicrocytic anemia. The sub-lethal exposure of leather dyes results into significant increase in the TLC, Intoxication leather dyes induces leukocytosis in which TLC increases. The increasing trend in lymphocytes count were also observed on exposure to leather dyes. The aim of the study was to check out the effect of leather dye pollution on fish fauna.
\end{abstract}

Keywords: Heamatology, Cirrhinus mrigala, MVC, TLC, Leather dyes, lymphocytes.

\section{INTRODUCTION}

Water drawn from the water sources is never the same after use. Inappropriate contamination of used water and the discharge of different industrial waste water into water sources often result in water pollution. In most cases, the water is contaminated with dangerous chemicals, radioactive materials, heavy metals or organic sludge. For this reason, dumping of the wastewater directly into waterways or oceans negatively impacts on aquatic life Acharya et al 2005. Humans, and the environment on various aspects. We consider ourselves intellectually and technologically better to our ancestors, we still adorn our physique, bearings, and homes with the skin of captured animals. But unlike the wholly biological methods used by our ancestors, the current leather industry is concurrently killing the local environment and the individuals that work there with a toxic slurry of elements. Global market for leather is growing, $\mathbf{2 3}$ billion square feet produced yearly is cost more than $\$ 77$ billion (US), as per recent estimations published in Guild Journal. Leather footwear is the largest outlet for the mess, esteemed at $\$ 47$ billion. More than $60 \%$ of the Global trade from the year 2010 onwards was largest worth about $\mathbf{\$ 1 2 . 3}$ billion and constituted $16 \%$ of the total Global trade. Leather clothing, home furnishings, and auto upholstery and miscellaneous other uses rounded out the remaining outlets with between 9 and 15\% shares. Chinese and Indian industries are the largest producer of among the world leaders with 6.8 billion square feet and 2.2 billion square feet, respectively, from the year 2013. Asia has engrossed a large amount of the labor tanning leather and turning it into belongings for Western markets Henelly et al 2007. Leather produced in a given area depends largely on the main source available. Globally skin supplemented by lamb, goat, buffalo, deer, ostrich, and yak. Exotic leathers are also pleasant more common. Kangaroo and bullwhips are often employed for motorcycle leathers, for its frivolous and abrasion-resistant nature. Tanning methods essentially one designed to shrivel a hide and stabilize the subsequent material so that it will not rot into an unusable form. The process for doing so first involves formulating the skin scraping it clean of hair, meat and fat, and optionally applying unbearable lime pastes, bleaching. Tanned leather, remains flexible in heat and will not decompose when wetted. The dye that is used to tan the leather is very harmful for aquatic fauna the present study is all about the leather dyes and their impact on aquatic fauna, Dalela, et al 2010.

The leather tanneries use highly toxic chemicals for tanning the leather which are released directly into water reservoirs. Effluent treatment facilities need to be established in order to limit the 
environmental damage caused by the direct dumping of untreated effluents, most of our present day environmental problems can be attributed to ecological misbehavior in the form of pollution for natural water bodies by sewage and industrial wastes which is the possible hazard to public health directly and indirectly. The rapid industrialization and successful green revolution have introduced a large variety of chemicals in our environment . These toxic chemicals changes the quality of the water that affects the fish and other aquatic organisms Dhasarathan et al.2000 the dyes and other Oranphosphorus pesticides used in crop fields are highly toxic to the aquatic organisms including fish. Sreenivasan and Swaminathan 1996, several studies have been carried out on the toxicity of leather dyes and organophosphorus pesticides. Singh and Sahai 1984, proteins are important substances required by organisms in tissue building, and plays an important role in energy metabolism, Khanee et al. 1992 observed depletion in protein contents of various tissues of fish Oreochromis mossambicus during the exposure of deltamethrin plasma glucose levels have been used to measure long and short term stress in fish. Gill et al $\mathbf{1 9 9 0}$ observed glucose content in various tissues of fish, Puntius conchonius, exposed to an organophosphorus insecticides, phosphamidon increase in the glucose levels in bronchial tissue of an air birthing fish, Clarias batrachus treated with roger. Lipids play a vital role during the biochemical adaptations of organophosphrous pesticides phosphomidom in the cholesterol levels in brain, kidney and liver of the fish, Channa punctatus, Patil, et al 1998.

\section{MeThodology}

Three major steps are involved in differential count- preparation of smear, staining and microscopic observation. Take blood specimen with microhaematocrit capillary tube to clean grease free slides. Place the drop approximately $1 \mathrm{~cm}$ from the end of the slide. Place the slide on a flat table top. With the help of right hand, hold the spreader slide and placed the edge of the spreader just in front of the drop of blood. There was approximate angle of $45^{\circ}$ between the two slides. Drew the spreader back until it will touches the drop of blood. Let the blood ran along the edge of the spreader. Pushed the spreader to the end of the slide with a smooth quick movement, Now blood smear was dried quickly by waving it rapidly in the air. Cover the slide with undiluted Leishman's stain for two minutes. Added on the slide distilled water double of about the volume of stain. Allow the staining to continue for 5 to 7 minutes. Now wash the stain off in the stream of distilled water until it has acquired a pinkish tinge. Shaked off the water adhering to the slide and set the slide in an upright position in a drying rack. Kept the smeared surface of the slide facing down. First examined the stained smear under the low power for screening. Chose the portion of the blood smear slightly before the 'tail end' of the smear where there was only slight touching of the red cells. Placed a drop of immersion oil on the slide, directly on the smear and observed under 100X objective by touching with drop of immersion oil. Counting was done by narrow longitudinal strip method. Various types of WBC were identified by their nuclei and cytoplasmic granules. The cells were counted with hand tally counter upto 100 cells.

\section{Calculation}

Number of type of cell $\_$x 100

Differential leucocyte count $(\%)=\quad$ Total number of WBC

\section{MCV}

This is the average volume of red cells. Because the size of the cell is very small, the volume is expressed in femtoliters (fl). MCV was calculated by Wintrobe's method (1981).

$\operatorname{MCV}(\mathrm{fl})=\frac{\operatorname{PCV}(\%) \times 10}{\text { Total } \mathrm{RBC} \text { count }(\mathrm{X} 1012 / \mathrm{l})}$

Total leucocytes were counted by using improved Standard Neubauer Haemocytometer (Dacie and Lewis, 1968). All the apparatus were cleaned with sodium citrate and then dried. The sample blood was aspirated in the WBCs pipette upto 0.5 mark and then diluted by WBCs diluting fluid (Turk's fluid) upto mark 11.0. The blood was thoroughly mixed with diluting fluid by shaking well. The counting chamber was covered with a cover slip and charged with the diluted blood after discarding first few drops. When the WBCs had settled down, the counting chamber was examined under the high magnification of a research microscope. The cells were counted in four squares each containing sixteen smaller squares. 
Calculation dilution X 10

Total no. of WBCs counted X

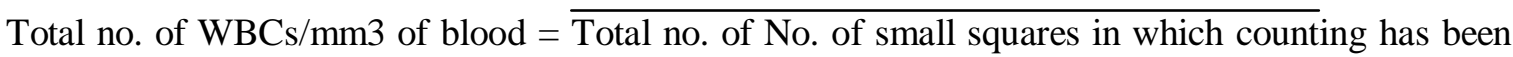
done

\section{RESULTS AND DISCUSSIONS}

The present study was carried out in the toxicological research lab., to check out the effect of two leather dyes Bismarck brown and Acid leather brown on fresh water teleost, Cirrhinus mrigala (Ham.) at different time intervals $24 \mathrm{hrs}, 48 \mathrm{hrs}, 96 \mathrm{hrs}$ and 1 week as in (tables 1-4 and figures A-D) Present investigation show decreasing trend in MCV on exposure to Bismarck brown and acid leather brown at different time intervals ( $24 \mathrm{hrs}, 48 \mathrm{hrs}$, $96 \mathrm{hrs}$ and 1 week) and at all three concentrations. However, the effect was more in acid leather brown exposure. Hilmy et al. (1980), Aruna (1987): Abidi and Srivastava (1988) show low level of MCV in Channa punctatus. Dalela et al. (1995) noted decreased MCV in Notopterus notopterus due to toxicity of chlordane and malathion. Decreased MCV also noted by Kumar and Patri (2000) in Anabas testudineus. Hymavathi and Rao (2000) resulted decreased MCV in Channa punctatus due to slaughter house pollution. The decreased MCV levels may be due to hypochromicmicrocytic anemia, Tyagi and Srivastava (2005) in Channa punctatus, Shah (2006) in Tinca tinca after short term exposure to lead, Parma et al. (2007) in Prochilodus lineatus after cypermethrin intoxication and Johal et al. (2007) in Cyprinus carpio. In Cirrhinus mrigala (Ham.). Increasing trend in TLC on exposure to Bismarck brown and acid leather brown at different time intervals ( $24 \mathrm{hrs}, 48 \mathrm{hrs}, 96 \mathrm{hrs}$ and 1 week) and at all three concentrations has been observed. However, the effect was more in acid leather brown exposure. The increase in the TLC was also reported by Garg and Tyagi (1989) in Heteropneustes fossilis due to manganese poisoning, while Goswami and Dutta (1991) in Heteropneustes fossilis due to aldrin and fenvalerate intoxication; Saxena and Chauhan (1994) in Heteropneustes fossilis due to copper sulphate intoxication; Nath and Banerjee (1995) in Heteropneustes fossilis treated with devithion; Singh (1995) in Channa punctatus due to copper sulphate and potassium dichromate induced toxicity, Raizada and Rana (1998) in Clarias batrachus, Gupta and Gupta (2000) in Heteropneustes fossilis, Ananadkumar et al. (2001) in Heteropneustes fossilis, Kumar and Malik (2006) in Clarias batrachus, Sanjib and Ashok (2006) in Heteropneustes fossilis after chromium sulphate treatment and Singh and Singh (2007) in Heteropneustes fossilis. In the present study the sub-lethal exposure of Bismarck brown and acid leather brown results into significant increase in the TLC. Intoxication of Bismarck brown and acid leather brown induces leukocytosis in which TLC increases. Leukocytosis in some cases may be due to protective reaction in which leukocyte protects the body when foreign substances (in present study fungicide) invade the body. Increase in number of leukocyte may also be found in leukemia.

The fishes were treated with leather dye Bismarck brown as in (table 1 and fig A after treatment with the value of lymphocyte was $50.1 \pm 0.40 \%$ in control set after $0.6 \mathrm{mg} / \mathrm{l}$ while as the value of lymphocyte was $51.5 \pm 0.74,53.0 \pm 0.46,55.2 \pm 0.26$ and $55.9 \pm 0.16 \%$ after $24 \mathrm{hrs}, 48 \mathrm{hrs}, 96 \mathrm{hrs}$ and 1 week treatment, the increase was significant after $24 \mathrm{hrs}, 48 \mathrm{hrs}, 96 \mathrm{hrs}$ and 1 week treatment. The value of lymphocyte was $49.9 \pm 0.32 \%$ in control set after $0.7 \mathrm{mg} / \mathrm{l}$ while as the value of lymphocyte was $53 \pm 0.53,55.9 \pm 0.90,56.8 \pm 0.85$ and $57.5 \pm 0.49 \%$ after $24 \mathrm{hrs}, 48 \mathrm{hrs}, 96 \mathrm{hrs}$ and 1 week treatment, the increase was significant after $24 \mathrm{hrs}, 48 \mathrm{hrs}, 96 \mathrm{hrs}$ and 1 week treatment .The value of lymphocyte was $49.8 \pm 0.13 \%$ in control set after $0.8 \mathrm{mg} / \mathrm{l}$ while as the value of lymphocyte was $53.1 \pm 0.13,56.2 \pm 0.61,57.1 \pm 0.64$ and $57.9 \pm 0.58 \%$ after $24 \mathrm{hrs}, 48 \mathrm{hrs}, 96 \mathrm{hrs}$ and 1 week treatment, the increase was significant after $24 \mathrm{hrs}, 48 \mathrm{hrs}$, $96 \mathrm{hrs}$ and 1 week treatment respectively. Present investigation show increasing trend in lymphocyte exposure to Bismarck brown at different time intervals ( $24 \mathrm{hrs}, 48 \mathrm{hrs}, 96 \mathrm{hrs}$ and 1 week) and at all three concentrations exposure. Increase in lymphocyte percent may be due to the toxic effect of leather dyes on blood and circulatory system. These results are in affirmation to Srivastava et al.(1995), Patil and Jabde (1998) after mercuric chloride intoxication in Channa gachua, Nath and Banerjee (1999) in Anabas testudineus, Saxena et al. (2003) in Gambusia affinis, Acharya et al. (2005) in Labeo rohita, Kumar and Malik (2006) in Clarias batrachus, Johal et al. (2007) in Cyprinus carpio.

\section{ACKNOWLEDGEMENT}

I am thankful to Dean of the College Dr Abdulla Haminie and head of the department Dr Hamid Er Norine for their support and suggestions to finalize the work. 
Industrial Pollution and its Ill Effects on Aquatic Fauna

Table1. Mean corpuscular volume (fl) in Cirrhinus mrigala (Ham.) after Bismarck brown treatment

\begin{tabular}{|c|c|c|c|c|c|}
\hline Conc. & $\begin{array}{l}\text { Control } \\
\text { (Mean+S.Em.) }\end{array}$ & $\begin{array}{l}24 \mathrm{hrs} \\
\text { (Mean+S.Em.) }\end{array}$ & $\begin{array}{l}48 \mathrm{hrs} \\
\text { (Mean+S.Em.) }\end{array}$ & $\begin{array}{l}96 \mathrm{hrs} \\
\text { (Mean+S.Em.) }\end{array}$ & $\begin{array}{l}1 \text { week } \\
\text { (Mean+S.Em.) }\end{array}$ \\
\hline $0.6 \mathrm{mg} / \mathrm{L}$ & $54.70 \pm 0.60$ & $53.20 \pm 0.41 *$ & $51.24 \pm 0.49 * *$ & $49.42 \pm 0.41 * *$ & $48.23 \pm 0.06^{* * *}$ \\
\hline $0.7 \mathrm{mg} / \mathrm{L}$ & $52.57 \pm 0.46$ & $50.13 \pm 0.57 *$ & $49.22 \pm 0.95^{*}$ & $49.28 \pm 1.49 * *$ & $48.21 \pm 1.02 * *$ \\
\hline $0.8 \mathrm{mg} / \mathrm{L}$ & $53.45 \pm 0.36$ & $50.01 \pm 0.27 * *$ & $48.20 \pm 0.15^{* * *}$ & $48.00 \pm 0.20 * * *$ & $47.01 \pm 0.91 * * * *$ \\
\hline
\end{tabular}

* Non significant $(P>0.05)$, ** Significant $(P<0.05)$

*** Highly significant $(P<0.01)$, **** Very highly significant $(P<0.001)$

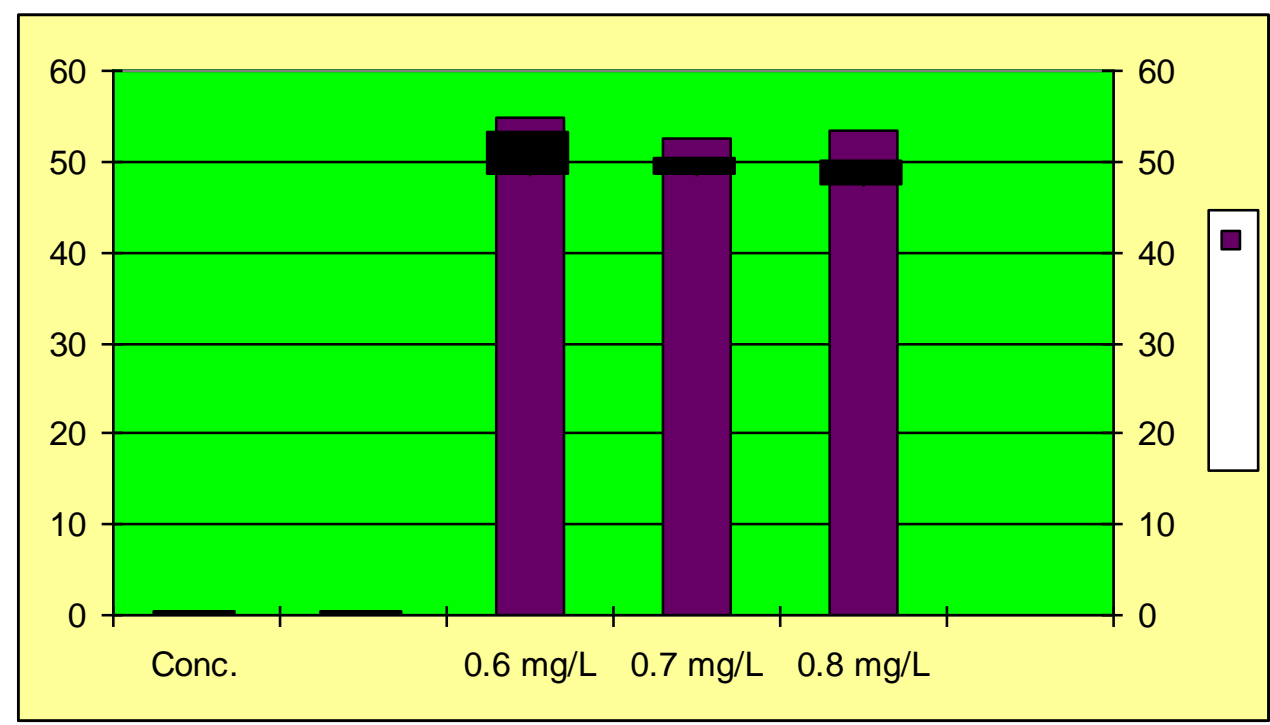

FigA.

Table2. Mean corpuscular volume (fl) in Cirrhinus mrigala (Ham.) after acid leather brown treatment

\begin{tabular}{|c|c|c|c|c|c|}
\hline Conc. & $\begin{array}{l}\text { Control } \\
\text { (Mean+S.Em.) }\end{array}$ & $\begin{array}{l}24 \mathrm{hrs} \\
\text { (Mean+S.Em.) }\end{array}$ & $\begin{array}{l}48 \text { hrs } \\
\text { (Mean+S.Em.) }\end{array}$ & $\begin{array}{l}96 \text { hrs } \\
(\text { Mean+S.Em.) }\end{array}$ & $\begin{array}{l}1 \text { week } \\
\text { (Mean+S.Em.) }\end{array}$ \\
\hline $8 m g / L$ & $54.70 \pm 0.60$ & $53.50 \pm 0.45^{*}$ & $51.74 \pm 0.39 * *$ & $49.49 \pm 0.49 * *$ & $48.69 \pm 0.16^{* * *}$ \\
\hline $9 \mathrm{mg} / \mathrm{L}$ & $52.57 \pm 0.46$ & $50.18 \pm 0.57 *$ & $49.32 \pm 0.95^{*}$ & $49.35 \pm 1.37 * *$ & $48.67 \pm 1.01 * *$ \\
\hline $10 \mathrm{mg} / \mathrm{L}$ & $53.45 \pm 0.36$ & $50.2 \pm 0.29 *$ & $48.56 \pm 0.45 * *$ & $48.21 \pm 0.10 * * *$ & $47.11 \pm 0.51 * * *$ \\
\hline
\end{tabular}

* Non significant $(P>0.05)$, ** Significant $(P<0.05)$

*** Highly significant $(P<0.01)$

**** Very highly significant $(P<0.001)$

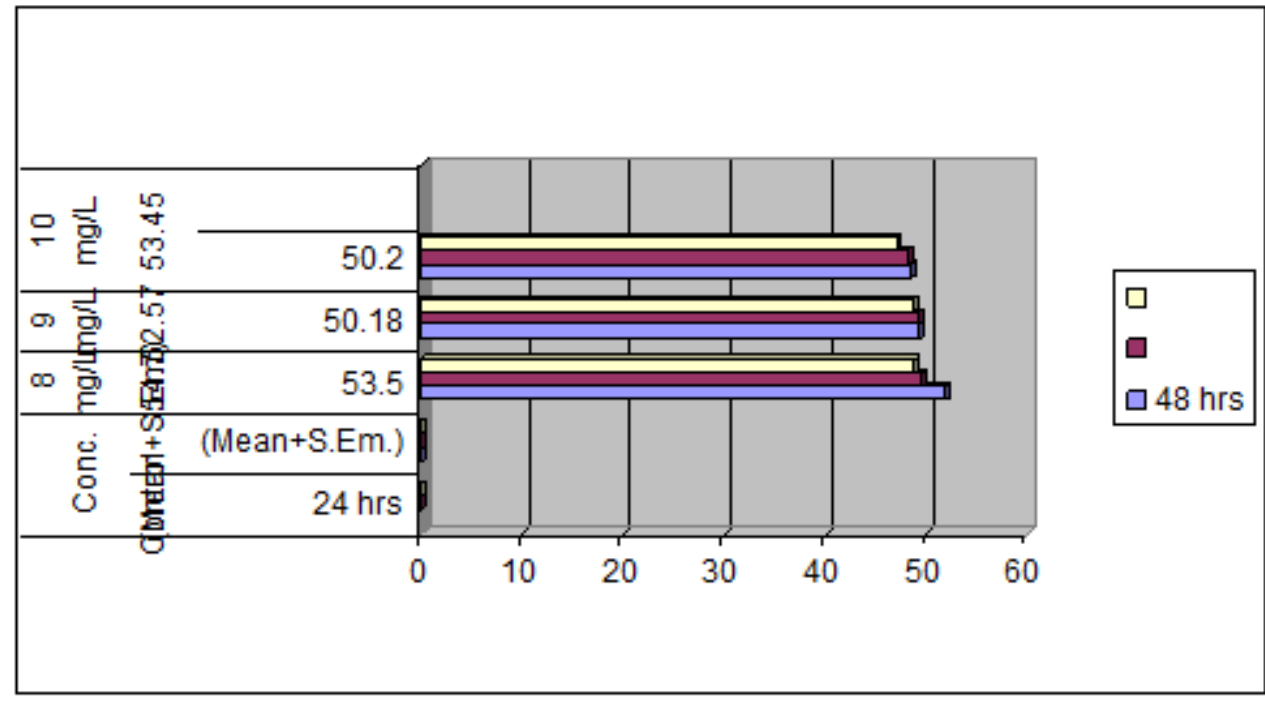

FigB. 
Table3. Total leucocyte count $\left(10^{9} / \mathrm{L}\right)$ in Cirrhinus mrigala (Ham.) after Bismarck brown treatment

\begin{tabular}{|c|c|c|c|c|c|}
\hline Conc. & $\begin{array}{c}\text { Control } \\
(\text { Mean }+ \text { S.Em. })\end{array}$ & $\begin{array}{c}24 \mathrm{hrs} \\
\text { (Mean+S.Em.) }\end{array}$ & $\begin{array}{c}48 \mathrm{hrs} \\
\text { (Mean+S.Em.) }\end{array}$ & $\begin{array}{c}96 \mathrm{hrs} \\
\text { (Mean+S.Em.) }\end{array}$ & $\begin{array}{c}1 \text { week } \\
(\text { Mean } \pm \text { S.Em.) }\end{array}$ \\
\hline $0.6 m g / L$ & $2.33 \pm 0.52$ & $2.39 \pm 0.09 *$ & $2.45 \pm 0.07 *$ & $2.75 \pm 0.01 * *$ & $2.92 \pm 0.03 * * *$ \\
\hline $0.7 \mathrm{mg} / \mathrm{L}$ & $2.31 \pm 0.42$ & $2.38+0.09 *$ & $2.48+0.08 * *$ & $2.78 \pm 0.03 * * *$ & $2.98 \pm 0.03 * * *$ \\
\hline $0.8 \mathrm{mg} / \mathrm{L}$ & $2.23 \pm 0.52$ & $2.44+0.06 * *$ & $2.53 \pm 0.05 * * *$ & $2.80 \pm 0.02 * * *$ & $3.02+0.02 * * * *$ \\
\hline
\end{tabular}

* Non significant $(P>0.05), * *$ Significant $(P<0.05), * * *$ Highly significant $(P<0.01)$

**** Very highly significant $(P<0.001)$

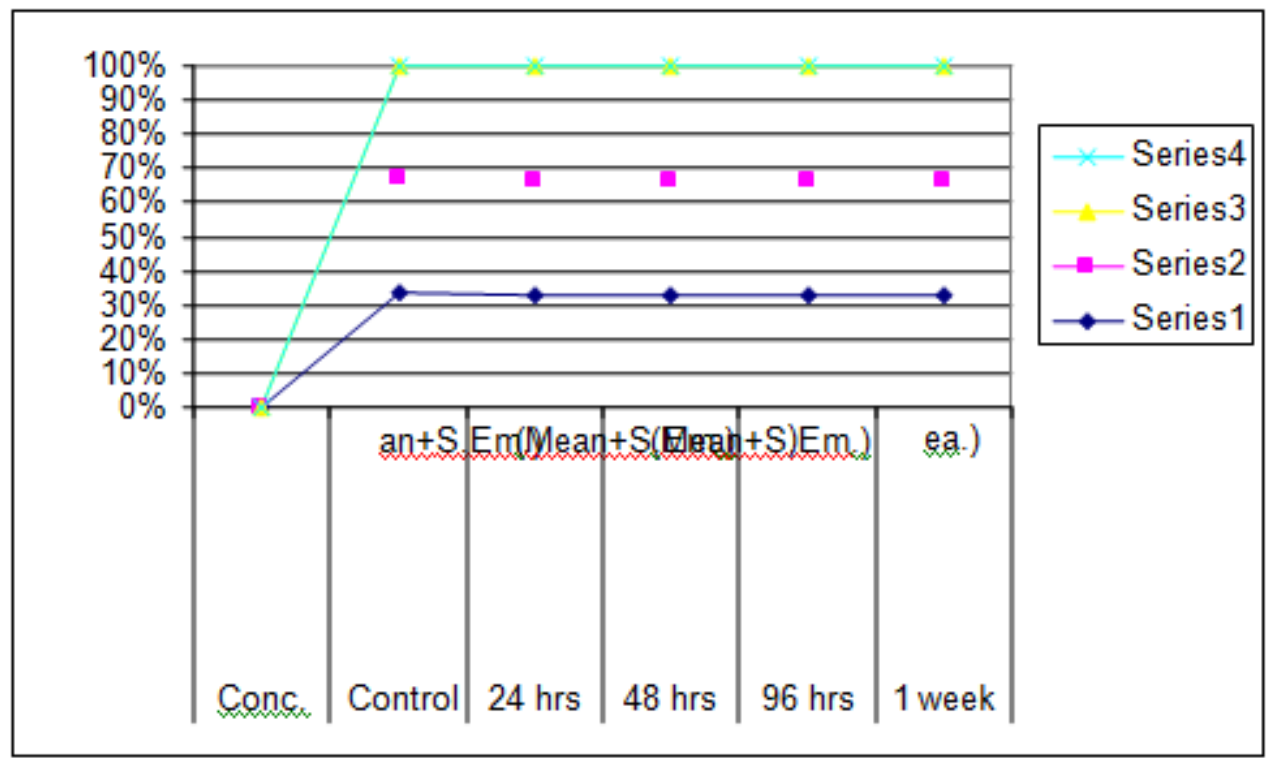

FigC.

Table4. Total leucocyte count $\left(10^{9} / \mathrm{L}\right)$ in Cirrhinus mrigala (Ham.) after acid leather brown treatment

\begin{tabular}{|c|c|c|c|c|c|}
\hline Conc. & $\begin{array}{c}\text { Control } \\
\text { (Mean+S.Em.) }\end{array}$ & $\begin{array}{c}24 \text { hrs } \\
\text { (Mean+S.Em.) }\end{array}$ & $\begin{array}{c}48 \mathrm{hrs} \\
\text { (Mean+S.Em.) }\end{array}$ & $\begin{array}{c}96 \mathrm{hrs} \\
\text { (Mean+S.Em.) }\end{array}$ & $\begin{array}{c}1 \text { week } \\
\text { (Mean+S.Em.) }\end{array}$ \\
\hline $8 m g / L$ & $2.33 \pm 0.52$ & $2.43+0.10 *$ & $2.48+0.07 *$ & $2.79 \pm 0.11 * *$ & $2.98+0.13 * * *$ \\
\hline $9 \mathrm{mg} / \mathrm{L}$ & $2.31 \pm 0.42$ & $2.42 \pm 0.08 *$ & $2.49 \pm 0.18^{* *}$ & $2.68 \pm 0.04 * * *$ & $2.88 \pm 0.09 * * *$ \\
\hline $10 \mathrm{mg} / \mathrm{L}$ & $2.23 \pm 0.52$ & $2.42 \pm 0.01 * *$ & $2.50 \pm 0.09 * * *$ & $2.59 \pm 0.11 * * *$ & $2.99 \pm 0.10 * * * *$ \\
\hline
\end{tabular}

* Non significant $(P>0.05), * *$ Significant $(P<0.05), * * *$ Highly significant $(P<0.01)$

**** Very highly significant $(P<0.001)$

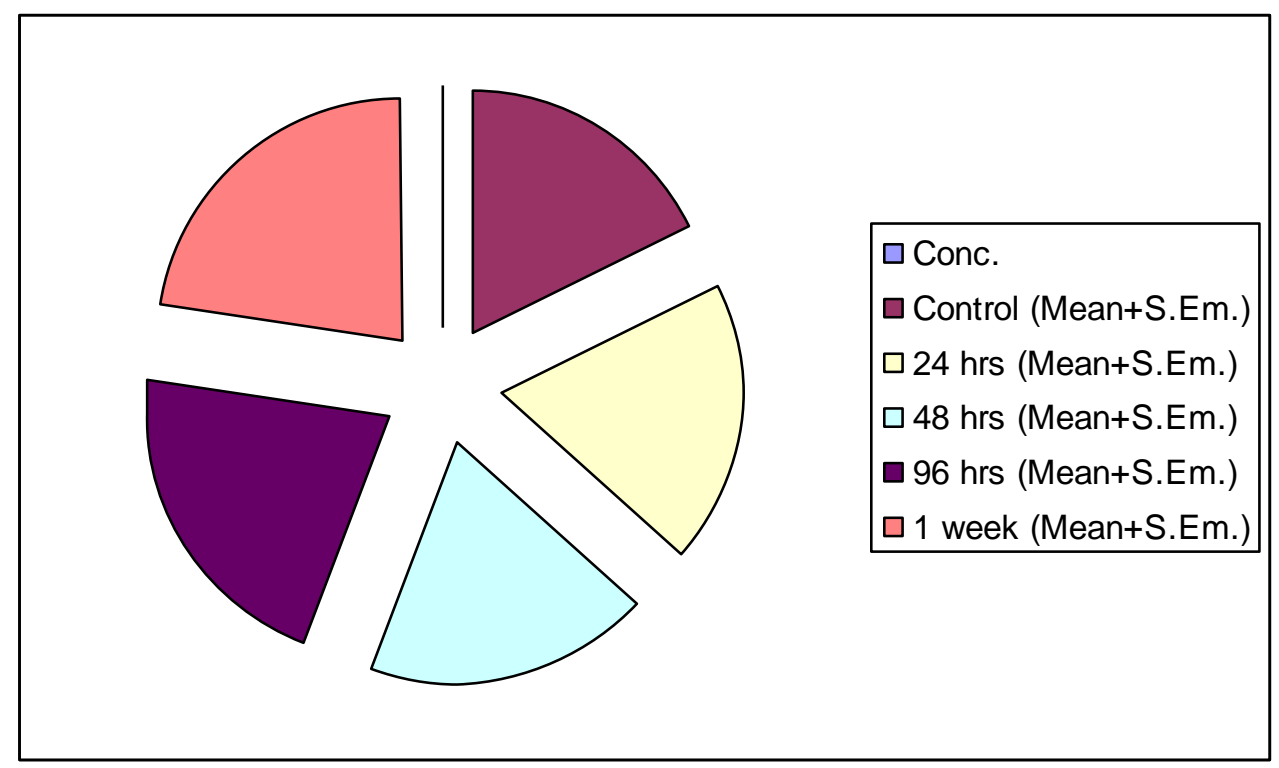

FigD. 
Table5. Lymphocyte (\%) in Cirrhinus mrigala (Ham.) after Bismarck brown treatment

\begin{tabular}{|c|c|c|c|c|c|}
\hline Conc. & $\begin{array}{c}\text { Control } \\
(\text { Mean } \pm \text { S.Em. }) \\
\end{array}$ & $\begin{array}{c}24 \text { hrs } \\
(\text { Mean } \pm \text { S.Em. })\end{array}$ & $\begin{array}{c}48 \text { hrs } \\
(\text { Mean } \pm \text { S.Em. }) \\
\end{array}$ & $\begin{array}{c}96 \text { hrs } \\
(\text { Mean+S.Em.) }\end{array}$ & $\begin{array}{c}1 \text { week } \\
(\text { Mean } \pm \text { S.Em. }) \\
\end{array}$ \\
\hline $0.6 \mathrm{mg} / \mathrm{L}$ & $50.1 \pm 0.40$ & $51.5 \pm 0.74 *$ & $53.0 \pm 0.46 * * *$ & $55.2 \pm 0.26 * * *$ & $55.9 \pm 0.16^{* * *}$ \\
\hline $0.7 \mathrm{mg} / \mathrm{L}$ & $49.9 \pm 0.32$ & $53+0.53 * *$ & $55.9 \pm 0.90 * * *$ & $56.8 \pm 0.85^{* * *}$ & $57.5 \pm 0.49 * * * *$ \\
\hline $0.8 \mathrm{mg} / \mathrm{L}$ & $49.8+0.13$ & $53.1+0.13 * *$ & $56.2 \pm 0.61 * * *$ & $57.1 \pm 0.64 * * * *$ & $57.9 \pm 0.58 * * * *$ \\
\hline
\end{tabular}

* Non significant $(P>0.05)$, ** Significant $(P<0.05)$

*** Highly significant $(P<0.01)$

**** Very highly significant $(P<0.001)$

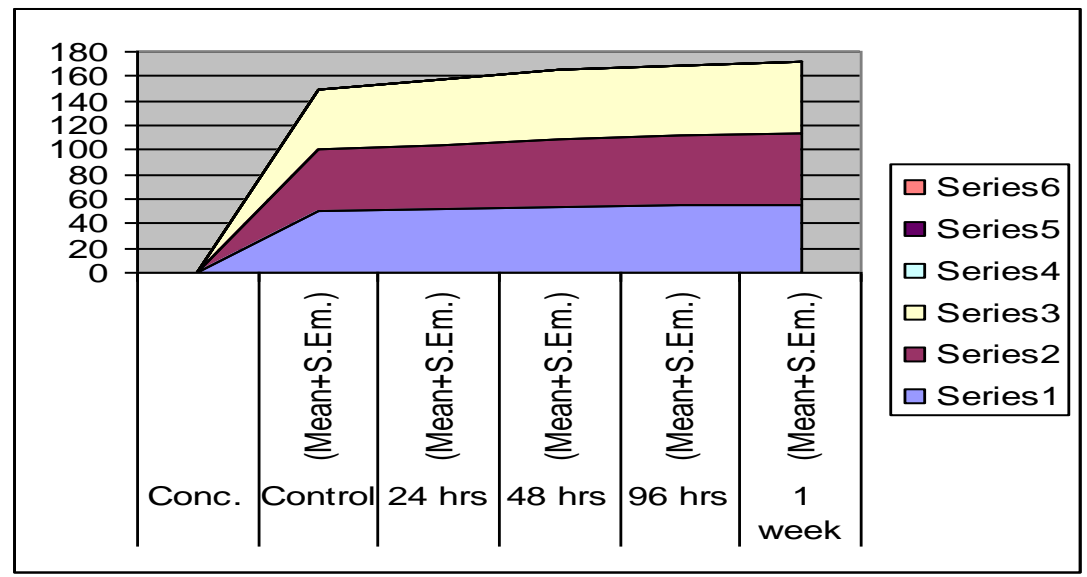

FigE.

\section{REFERENCES}

Abidi, R. and Srivastava, U.S. (1988)- Effect of endosulfan on certain aspects of hematology of the fish Channa punctatus (Bloch.) Proc. Nat. Acad. Sci. India, 58(B). I.

Acharya,S., Dutta, T. and Das, M. K. (2005)- Influence of sublethal ammonia toxicity on some physiological parameters of Labeo rohita (Ham.). J. Ecotoxicol. Environ. Monit., 26(4): 615-620.

Acharya,S., Dutta, T. and Das, M. K. (2005)- Influence of sublethal ammonia toxicity on some physiological parameters of Labeo rohita (Ham.). J. Ecotoxicol. Environ. Monit., 26(4): 615-620.

Anandkumar, A., Tripathy, A.P. and Tripathy, N.K. (2001)- Effect of dimecron on the blood parameters of Heteropneustes fossilis. J. Env. Biol., 22(4): 297-299.

Aruna, D. and Gopal, V. (1987)- Toxic effect of sublethal level of mercury on hematological parameters. Indian J. Environ. Hlth., 29(1): 52-56.

Dalela, R.C., Rani, S., Kumar, V. and Verma, S.R. (1995)- In vitro haematological alterations in a fresh water teleost, M. vittatus following sub-acute exposure to pesticides and their combinations. J. Environ. Biol., 2 (2): 79-86.

Dhasarathan, P., Palaniappan, R.and Ranjit Singh, A.J.A (2000)- Effect of endosulfan and butachlor on the digestive enzyme and proxtimate composition of the fish, Cyprinus carpio, Indian J.Environ and Ecoplan., 3(3):61-614.

Garg, V. K., Garg, S. K. and Tyagi, S. K. (1989)- Manganese induced hematological and biochemical anomalies in Heteropneutes fossilis (Bloch.). J. Environ. Biol., 10: 349-353.

Gill, T.S.,Pande,J.and Tewari, H. (1990)- Enzyme modulation by sublethal concentration of aldicarb, phospnamidom and endosulfan in fish tissue. Pestic. Biochem.Physiol., 38:231-244.

Goswami, U.C. and Dutta, N.K. (1991)- Vitamin A - deficient diet and its effect on certain hematological parameters of $\mathrm{H}$. fossilis a 3-4-dehydro rethinal rich fresh water fish. Int. J. Vitam. Nutr Res., 61(3): 205-09.

Gupta, A.K. and Gupta, S. (2000)- Toxic effect of chloradane and malathion on certain haematological parameters of a fresh water teleost, Notopterus notopterus. J. Envir. Biol., 16 (3): 219-223.

Hilmy, A.M., Shabana, M.B. and Said, M.M. (1980)- Haematological response to mercury toxicity in the marine teleost, Aphanius dispar (Rupp.). Comp. Biochem. Physiol., 67: 147-158.

Hymayathi, V. and Rao L.M. (2000)- Effect of sublethal concentration of lead on the hematology and biochemical constituents of Channa punctatus. Bull. Pure Appl. Sci., 19: 1-5. 
Johal, M.S., Sharma, M.L. and Ravneet, S. (2007)- Impact of low dose of organophosphate monocrotophos on the epithelial cell of gills of Cyprinus carpio (Linn.) SEM study. J. Environ. Biol., 28(3): 663-667.

Johal, M.S., Sharma, M.L. and Ravneet, S. (2007)- Impact of low dose of organophosphate monocrotophos on the epithelial cell of gills of Cyprinus carpio (Linn.) SEM study. J. Environ. Biol., 28(3): 663-667

Johal, M.S., Sharma, M.L. and Ravneet, S. (2007)- Impact of low dose of organophosphate monocrotophos on the epithelial cell of gills of Cyprinus carpio (Linn.) SEM study. J. Environ. Biol., 28(3): 663-667.

Khanee,N.James.R.and Manjuladevi,N.(1992)- Sublethal effect or deltamethrin on the rates of excretion and metabolism and protein changes in Oreochromis mossambicus, J. Ecobiol., 4:81-85.

Kumar, K. and Patri, P. (2000)- Variation in the hematology of starved climbin perch Anabas testudines (Bloch.), a fresh water air breathing fish. Aquacult., 1 No-1. 19-24.

Kumar, Y. and Malik, M. (2006)-Haematology of freshwater fish-Cirrhinus mrigala (Ham.). J. Exp. Zool. India, 9(1): 141-148.

Kumar, Y. and Malik, M. (2006)-Haematology of freshwater fish- Cirrhinus mrigala (Ham.). J. Exp. Zool. India, 9(1): 141-148.

Kumar, Y. and Malik, M. (2006)-Haematology of freshwater fish- Cirrhinus mrigala (Ham.). J. Exp. Zool. India, 9(1): 141-148.

Nath, R. and Banerjee, V. (1995)- Sub-lethal effects of devithion on the haematological parameters in Heteropneustes fossilis (Bloch.). J. Fresh Water Biol., 7 (4): 261-264.

Nath, R. and Banerjee, V. (1999)- Influence of lethal and sub-lethal toxicity of rogor on the blood parameters of fresh water fish, Heteropneustes fossilis (Bloch.). Env. Eco., 17 (4): 940-944.

Nath, R. and Banerjee, V. (1999)- Influence of lethal and sub-lethal toxicity of rogor on the blood parameters of fresh water fish, Heteropneustes fossilis (Bloch.). Env. Eco., 17 (4): 940-944.

Parma, M.J., Loteste, A., Campana, M. and Bacchetta, C. (2007)- Changes of haematological parameters in Prochilodus lineatus exposed to sub-lethal concentration of cypermethrin. J. Environ. Biol., 28(1): 147-149.

Patil, S.S. and Jabde, P.V. (1998)- Effect of mercury poisoning on some haematological parameters from a freshwater fish, Channa pounctatus. Pollut. Res., 17: 223-228.

Patil, S.S. and Jabde, P.V. (1998)- Effect of mercury poisoning on some haematological parameters from a freshwater fish, Channa pounctatus. Pollut. Res., 17: 223-228.

Raizada, S. and Rana, K. S. (1998)-Acute toxicity of malachite green to an air breathing teleost-Clarais batrachus (Linn.). J. Environ. Biol., 19(3): 237-241.

Sanjib, S. J. and Ashok, K. (2006)-Effect of chromium sulphate on hematological factors of the fishHeteropneusts fossilis (Bloch.). J. Ecotoxicol. Environ. Monit., 16(4): 363-370.

Sarka, S.S and Nandhi, J.(1991)- Toxic effects of organophosphorus insecticide to fish. Curr.Sci., 15:397398.

Saxena, K.K. and Chauhan, R.R.S. (1994)- Copper sulphate induced haematological and biochemical anomalies in the Indian catfish, Heteropneustes fossilis (Bloch.). Uttar Pradesh J. Zool., 14 (2): 161 163.

Saxena, O. P. and Sharma, S. (2003)-Effects of acute chronic toxicity of four household detergents on RBC count and their morphology in a freshwater fish-Gambusia affinis (Bloch.). Toxicol. Int., 1(20): 95103.

Saxena, O. P. and Sharma, S. (2003)-Effects of acute chronic toxicity of four household detergents on RBC count and their morphology in a freshwater fish- Gambusia affinis (Bloch.). Toxicol. Int., 1(20): 95103.

Shah, S.L. (2006)- Haematological parameters in tench Tinca tinca after short term exposure to lead. J. Appl. Toixicol., 26(3): 223-228.

Singh, M. (1995)-Hematological responses in a freshwater teleost- Channa punctatus (Bloch.) to experimental copper and chromium poisoning. J. Environ. Biol., 16(4): 339-341.

Singh, P.B. and Singh, V. (2007)- Endosulfan induced changes in phospholipids in the fresh water female catfish Heteropneustes fossilis (Bloch.). J. Environ. Biol., 28(30): 605-610.

Singh,S. and Sahai, S. (1984)- Malathion on the mortality and behaviour of the fresh water teleost.J.Enverion.Biol., 5(1):23-28.

Sreenivasan, A and Swaminathan.G.K.O. (1967)- Toxicity of six organophosphorus insecticides to fish, Curr.Sci., 15:397-398. 
Srivastava, S. J., Singh, N. D., Srivastava, A. K. and Sinha, R. (1995)-Acute toxicity of malachite green and its effects on certain blood parameters of a catfish-Heterapneustes fosssilis (Bloch.). Aquaculture Toxicol., 31(3): 241-247.

Srivastava, S. J., Singh, N. D., Srivastava, A. K. and Sinha, R. (1995)-Acute toxicity of malachite green and its effects on certain blood parameters of a catfish-Heterapneustes fosssilis (Bloch.). Aquaculture Toxicol., 31(3): 241-247.

Tyagi A. and Srivastava, N. (2005)- Haematological response of fish Channa punctatus (Bloch.) to chronic zinc exposure. J. Env. Biol., 26 (2): 429-32.

Citation: S. Gowhar, "Industrial Pollution and its Ill Effects on Aquatic Fauna", International Journal of Advanced Research in Chemical Science (IJARCS), vol. 4, no. 12, pp. 24-31, 2017. http://dx.doi.org/10.20431/ 2349-0403.041200

Copyright: (C) 2017 Authors. This is an open-access article distributed under the terms of the Creative Commons Attribution License, which permits unrestricted use, distribution, and reproduction in any medium, provided the original author and source are credited. 